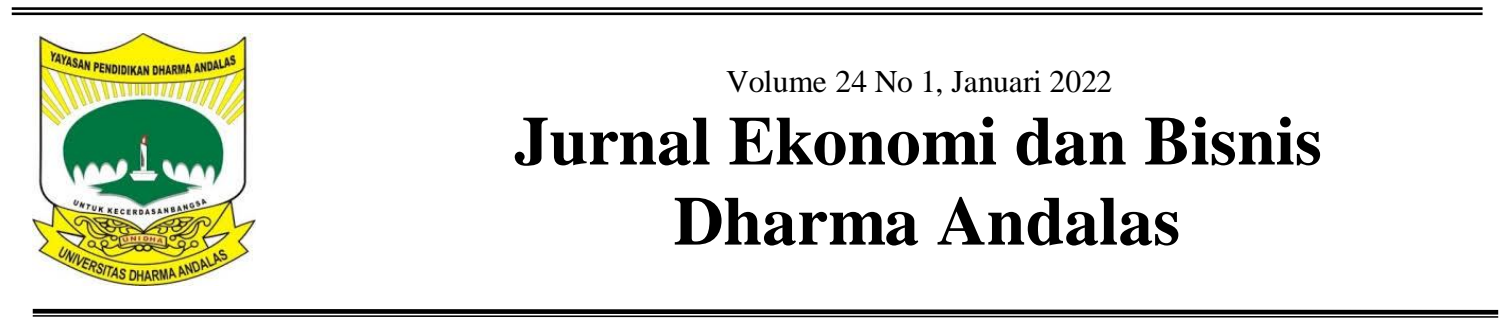

\title{
Pengaruh Tata Letak Produksi Terhadap Efisiensi Usaha dan Daya Saing UD. Barokah Lamongan
}

\author{
Ival Abdi Hilmansyah ${ }^{1}$, Wiwik Handayani ${ }^{2}$ \\ Universitas Pembangunan Nasional "Veteran" Jawa Timur ${ }^{1,2}$ \\ email : ivalhilmansyah99@gmail.com ${ }^{1}$ \\ wiwik.em@upnjatim.ac.id ${ }^{2}$
}

\begin{abstract}
UD. Barokah Lamongan is a Small and Medium Enterprise (UMKM) that produces snacks which have problems in the production layout which causes operational costs to increase and production efficiency so that the production target cannot be achieved and wants to increase the competitiveness of the company so that it is superior. Basically when running this business to get maximum profit and profit with minimal funds and operational costs. The purpose of this research is to improve efficiency by improving the production layout which will have an impact on reducing operational costs and will increase production output and increase the competitiveness of the company. This research uses descriptive quantitative methods to provide a detailed description of the complete symptoms and phenomena objectively, and data collection is done by interview and direct observation, after the data is collected and carried out with a rectilinear formula. The tool used in improving the layout is the blockplan software. The block plan is used to design the layout efficiency and a comparison is made with the layout before and after. The results of this study prove that the new layout design can create an efficiency level of material handling costs of Rp. 278,635,896/year or $64.1 \%$. And maximize the production of macaroni by 8,500 balls / month, fried meatballs by 2,600 balls / month, so that it has an impact on increasing company profits and increasing competitiveness of companies. because competitiveness is the ability of entrepreneurs to produce goods or services that are acceptable to the public and whose sales are better than similar competitors.
\end{abstract}

Keywords: layout improvement, production efficiency, competitiveness, blockplan

\begin{abstract}
ABSTRAK
UD. Barokah Lamongan merupakan Usaha Kecil Menengah (UMKM) yang memproduksi makanan ringan yang memiliki masalah dalam tata letak produksi yang menyebabkan membesarnya ongkos operasional usaha serta efisiensi produksi yang mengakibatkan target produksi belum bisa tercapai dan ingin meningkatkan daya saing perusahaannya agar lebih unggul. Pada dasarnya saat menjalankan usaha dituntut untuk mendapatkan laba dan keuntungan yang maksimal dengan dana dan biaya operasional minimal. Tujuan dalam penelitian ini adalah untuk melakukan efisiensi dengan cara memperbaiki tata letak produksi yang akan berdampak pada pengurangan biaya operasional dan akan bertambahnya output produksi serta meningkatkan daya saing perusahaan. Dalam penelitian ini menggunakan metode deskriptif kuantitatif memberikan gambaran secara detail tentang gejala dan fenomena yang lengkap secara objektif, dan pengumpulan datanya dengan wawancara serta observasi secara langsung, setelah data terkumpul dan dilakukan perhitungan dengan rumus rectilinier. Alat bantu yang digunakan dalam perbaikan tata letak adalah dengan software blocplan. Blocplan digunakan untuk perancangan efisiensi tata letak serta dibuat perbandingan dengan tata letak sebelum dan setelah perbaikan. Hasil dari penelitian ini membuktikan bahwa desain tata letak baru dapat menciptakan tingkat efisiensi dari ongkos material handling sebesar Rp. 278,635,896/tahun atau
\end{abstract}


$64,1 \%$. Dan memaksimalkan produksi makaroni sebesar 8.500 ball/bulan, bakso goreng sebesar 2.600 ball/bulan, sehingga berdampak pada bertambahnya keuntungan perusahaan serta daya saing perusahaan yang semakin maju. karena daya saing merupakan kemampuan para pengusaha untuk menghasilkan barang atau jasa yang dapat diterima masyarakat serta penjualannya lebih baik dari pesaing sejenisnya.

Kata Kunci: perbaikan tata letak, efisiensi produksi, daya saing, blocplan

\section{PENDAHULUAN}

Para pengusaha saat ini dituntut harus siap dengan situasi yang cepat berubah dan tidak menentu dalam menjalankan usahanya, strategi jangka panjang sangat dibutuhkan untuk menjalankan usaha dalam persaingan pasar dunia saat ini. Perusahaaan maupun industri harus bisa menyediakan produknya sesuai dengan kemauan serta kebutuhan pembeli yang semakin beraneka ragam (Abdilla \& Agus, 2021). Dengan semakin ketatnya persaingan di pasar global saat ini. perusahaan semakin dituntut untuk meningkatkan kinerja sistem produksinya agar lebih kompetitif, efisien dan untuk meningkatkan pangsa pasar (Araújo et al., 2017).

\section{Menurut}

2019)Industri makanan

(Damaledo, produksi oleh Usaha Kecil Menengah (UKM) yang dimana harus bersama-sama kita dukung agar terus mengalami perkembangan dan mampu bersaing dengan industri besar di Indonesia, dari survei State of Snacking pada tahun ini trend konsumsi makanan ringan Indonesia naik sebesar $71 \%$ jika dibandingkan tahun lalu sebesar 64\%, untuk kedepannya diharapkan para produksi industri makanan ringan mampu berkembang hingga melakukan ekspor produknya kepasar mancanegara. Menurut (Damaledo, 2019) dari data kementrian perindustrian trend industri makanan ringan memang terus mengalami pertumbuhan dari tahun 2018-2019 sebesar 2,02\% dan tahun 2019-2020 sebesar 3,06\% hal ini dibuktikannya kebiasaan masyarakat Indonesia yang suka ngemil untuk membangun kedekatan sosial ataupun kedekatan antar individu ataupun makanan ringan dijadikannya suguhan dalam berbagai acara.

Mengingat persaingan usaha pada industri makanan ringan yang sangat ketat, para produsen makanan ringan harus menerapkan beberapa strategi untuk bisa memenangkan persaingan usaha untuk menguasai pasar, beberapa strategi yang dapat diterapkan salah satunya adalah menerapkan proses produksi yang efisien dengan cara memperbaiki alur proses produksi atau tata letak produksi, melakukan riset pasar terlebih dahulu, dan melakukan perbaikan kinerja karyawan.

Efisiensi produksi dengan memin imalkan jarak perpindahan merupakan salah satu cara yang harus dilakukan agar proses perencanaan produksi tercapai. Efisiensi dapat tercapai salah satunya dengan melakukan perbaikan tata letak fasilitas produksi. Melakukan perencanaan penataan pabrik merupakan bagian penting dalam menentukan efisiensi suatu kegiatan usaha jangka panjang. (Yuliarty \& Widiarto, 2014).

Penataan layout dapat mempunyai arti sebagai tata cara pengaturan peralatan-peralatan bagi yang menjalankan usaha untuk menunjang kelancaran proses produksinya. Persiapan dalam melakukan perbaikan tata letak untuk produksi ini juga mempunyai manfaat guna meningkatkan keterkaitan stasiun kerja (Vaidya et al., 2013). Jika tata letak fasilitas sudah optimal, terdapat manfaat yang besar bagi pemilik bisnis dalam menjalankan bisnisnya. Tata letak fasilitas produksi menentukan efisiensi produksi dalam jangka panjang dan akan berdampak pada waktu produksi yang lebih cepat, output produksi yang lebih banyak sehingga 
berdampak pada peningkatan keuntungan usaha yang lebih besar. Ketidakmampuan untuk melakukan pros es manufaktur dengan benar menyebabk an penundaan, ketidakfleksibelan, inefisiensi, persediaan berlebih, biaya tinggi, kualitas produk rendah, dan pelanggan yang tidak senang (Okpala et al., 2016).

Permasalahan tata letak sering dialami oleh beberapa UMKM (Usaha Kecil Menengah) khususnya yang baru berkembang, jika tidak segera diatasi akan menyebabkan permasalahan baru seperti aliran antar bahan baku semakin lama dan berdampak pada biaya operasional usaha yang besar. Untuk mewujudkan perencanaan layout untuk mengurangi jarak dan perputaran bahan baku yang efektif dan efisien memerlukan alat bantu untuk membantu mengatasi permasalahan dan akan segera dicari alternatif tata letak yang lebih baik. Ada beberapa metode atau alat bantu dapat dipakai untuk memperbaiki tata letak salah satunya adalah dengan menggunakan software blocplan. Menurut Siregar et al. (2013) Dalam melakukan Perancangan tata letak produksi dikerjakan dengan memakai metode blocplan serta dibutuhkannya peta keterkaitan hubungan aktivitas atau biasanya disebut Activity Relationship Chart (ARC). Data lapangan akan di proses di dalam software blocplan dan akan muncul alternatif layout usulan beserta nilai usulannya.

UD. Barokah adalah sebuah peru sahaan yang berlokasi di Dusun Pedurun gan, Desa Dukuhtunggal, Kecamatan Glagah, Kabupaten Lamongan. UD. Barokah bergerak di bidang produksi makanan ringan atau jajanan ringan seperti makaroni dan bakso goreng (basreng).

UD. Barokah harus terus meningkatkan produksinya agar terus bisa bersaing dengan kompetitor sejenisnya dan bisa memenangkan persaingan tersebut. Berikut merupakan data produksi dari kompetitor sejenis.

Tabel 1

Hasil Produksi Kompetitor UD. Djoyo Gresik

\begin{tabular}{ccc}
\hline Bulan \& Tahun & Hasil Produksi Makaroni & $\begin{array}{c}\text { Hasil Produksi } \\
\text { Basreng }\end{array}$ \\
\hline Januari 2021 & 8.200 Ball & 3.000 Ball \\
Februari 2021 & 8.500 Ball & 3.200 Ball \\
Maret 2021 & 9.000 Ball & 3.300 Ball \\
April 2021 & 9.600 Ball & 3.700 Ball \\
\hline
\end{tabular}

Sumber : UD. Djoyo Gresik

Dari data diatas dapat diketahui hasil produksi dari kompetitor UD. Djoyo Gresik yang menunjukkan bahwa produksinya lebih besar dari pada hasil produksi yang dihasilkan oleh UD. Barokah Lamongan yang dapat dilihat pada tabel 2. Maka dari itu harus dilakukan perbaikan pada proses produksi dari UD. Barokah agar tetap mempunyai daya saing dan dapat memenangkan persaingan terhadap kompetitor-kompetitor lainnya. Untuk meningkatkan daya saing dimulai dari memenangan persaingan lokal terlebih dahulu (Irawan, 2020)

UD Barokah memiliki waktu kerja 8 Jam untuk setiap hari dan 25 hari kerja

dalam sebulan Saat ini UD. Barokah sud ah mempunyai 18 karyawan yang memb antu mengembangkan usahanya. Berdasa rkan wawancara dengan pemiliknya maka pemilik mengungkapkan Permasalahan yang dihadapi UD. Barokah adalah efisiensi dan produktivitas yang kurang maksimal yang dikarenakan tata letak produksinya yang masih kurang maksimal sehingga menyebabkan tidak tercapainya target produksi yang sudah direncanakan, disisi lain juga menyebabkan biaya ongkos material handling yang sangat besar yang berdampak pada berkurangnya keuntungan perusahaan. 
Tabel 2

Hasil Produksi dan Target Produksi UD. Barokah Lamongan

\begin{tabular}{ccccc}
\hline $\begin{array}{c}\text { Bulan } \\
\boldsymbol{\&} \\
\text { Tahun }\end{array}$ & $\begin{array}{c}\text { Hasil } \\
\text { Produksi } \\
\text { Makaroni }\end{array}$ & $\begin{array}{c}\text { Target } \\
\text { Produksi } \\
\text { Makaroni }\end{array}$ & $\begin{array}{c}\text { Hasil } \\
\text { Produksi } \\
\text { Bakso } \\
\text { Goreng }\end{array}$ & $\begin{array}{c}\text { Target } \\
\text { Produksi } \\
\text { Bakso } \\
\text { Goreng }\end{array}$ \\
\hline $\begin{array}{c}\text { Januari } \\
2021\end{array}$ & 5.000 Ball & 8.000 Ball & 1.500 Ball & 3.000 Ball \\
$\begin{array}{c}\text { Februari } \\
2021\end{array}$ & 4.800 Ball & 8.000 Ball & 1.400 Ball & 3.000 Ball \\
$\begin{array}{c}\text { Maret } \\
2021\end{array}$ & 4.900 Ball & 8.000 Ball & 1.500 Ball & 3.000 Ball \\
$\begin{array}{c}\text { April } \\
2021\end{array}$ & 5.100 Ball & 8.000 Ball & 1.600 Ball & 3.000 Ball \\
\hline Sumber & UD Barokah Lamongan &
\end{tabular}

Sumber : UD. Barokah Lamongan

Berdasarkan tabel diatas diketahui hasil produksi masih belum memenuhi target yang mana hasil tertinggi dari produk makaroni pada bulan April sebesar 5.100 ball dengan target produksi sebesar 8.000 ball sedangkan untuk hasil produksi dari bakso goreng tertinggi pada bulan Maret sebesar 1.600 ball dengan target produksi sebesar 3.000 ball. Tata letak merupakan suatu hal yang menyebabkan masalah efisien dan efektifitas harus segera diperbaiki, karena tata letak produksi sangat berpengaruh terhadap hasil produksi. Biaya penanganan material dalam tata letak fasilitas adalah ukuran paling penting untuk menentukan efektivitas pengaturan dan merupakan kriteria yang sering digunakan dalam perbandingan pilihan lokasi (Turanoğlu \& Akkaya, 2018).

Berdasarkan permasalahan atau fenomena yang terjadi maka penelitian ini bertujuan untuk mengetahui proses perbaikan tata letak produksi untuk menciptakan efisiensi produksi dan meningkatkan daya saing pada industri makanan ringan pada UD. Barokah Lamongan.

Penelitian dari Habi Adi \& Handayani (2020) dengan menggunakan metode yang sama dalam perbaikan tata letak menghasilkan perolehan jarak antar stasiun kerja yang baru dan berhasil melakukan efisiensi pengurangan jarak dalam proses bongkar muat. Sedangkan penelitian dari Amalia et al., (2017) menunjukkan bahwa tata letak produksi baru dapat memperpendek jarak antar stasiun kerja. Penelitian tersebut dapat membantu mengembangkan usaha dari pengusaha kecil yang sedang berkembang.

Untuk melakukan proses produksi harus mengetahui manajemen produksi terlebih dahulu. Menurut Mufida et al. (2019) Manajemen produksi adalah kegiatan untuk menghasilkan sesuatu dalam prosesnya, dapat berupa barang (seperti baju, sepatu, makanan) maupun dalam jasa (perawatan, pijat, pangkas rambut, hiburan, manajemen). berkaitan ilmu ekonomi, istilah tersebut dikenal sebagai fungsi manajmen produksi yang menunjukkan hubungan langsung antara faktor-faktor produksi (input) dan produksi (output). Setiap output yang di produksi membutuhkan input yang berbeda (Muin, 2017).

Pengaturan yang terstruktur merupakan fasilitas yang penting untuk produksi barang atau pengiriman jasa (Hari Prasad et al., 2014). Tata letak fasilitas adalah studi yang memaksimalkan tingkat pemanfaatan mesin, meminimalkan gerakan yang tidak perlu, menghemat waktu, memungkinkan karyawan bekerja lebih efisien dan dengan demikian mengurangi biaya (Turanoğlu \& Akkaya, 2018). Desain tata letak fasilitas memiliki keterkaitan dengan pengaturan teknis yang terstruktur dari macam bagian komponen stasiun kerja, peralatan produksi seperti mesin, perangkat atau area penyimpanan, dan kawasan publik dalam industrial (Kovács \& Kot, 2017). Tantangan yang paling signifikan dalam desain tata letak fasilitas termasuk kompleksitas, dinamika, keacakan, simultanitas, biaya tinggi kurangnya integrasi dan prosedur standar, dan keselamatan (Zúñiga et al., 
2020). Tata letak yang sesuai dapat membantu menghasilkan keuntungan yang besar.

Menurut Tongur et al. (2020) penempatan fasilitas untuk produksi di wilayah pabrik, sering disebut sebagai masalah tata letak fasilitas, memiliki kerugian besar pada ongkos produksi, proses produksi, waktu tunggu produksi, dan produktivitasnya. Memudahkan proses manufaktur, dari itu meminimumkan proses manufaktur, meminimumkan pemindahan barang, memilihara fleksibilitas, memelihara perputaran barang, meminimalkan modal, menekan penggunaan ruangan, memaksimalkan efisiensi pekerja, memberikan keamanan bagi pekerja (Yuliarty \& Widiarto, 2014). Untuk merencanakan tata letak yang baik menurut Puspita et al. (2015) jika departemen memiliki hubungan yang kuat, itu adalah pilihan yang baik untuk menempatkan mereka secara dekat.

Jenis tata tata letak dapat bermacam-macam tergantung kondisi usahanya. Macam-macam tata letak menurut Nadia \& Lai-Soon (2016) yakni layout pemprosesan, tata letak untuk produk, jenis layout yang permanen. Sedangkan jenis tata letak menurut Tripathi (2020) yaitu tata letak, tulang belakang, produk, proses, celluler, hybrid, terdistribusi, berbentuk U, lingkaran, berbentuk sisir, bentuk bintang, berbasis aliran, gantungan. Tata letak yang terbaik merupakan tata letak yang dapat membantu pekerja untuk melakukan pekerjaannya dengan baik, tata letak yang terbaik menurut Kovács \& Kot (2017) dapat meminimalkan jarak total arus barang, biaya penanganan material dan waktu yang dihabiskan dalam sistem manufaktur. Sehingga menghasilkan barang lebih banyak dan keuntungan lebih besar. Saat menjalankan usaha terdapat faktor yang menyebabkan tata letak harus dirubah, ciri-ciri tata letak jika harus dilakukan perbaikan menurut Puspita et al. (2015) yaitu ketika terjadinya bactracking, penambahan mesin, tidak efektifnya produksi, biaya operasional yang terlalu besar.

Untuk melakukan penataan yang efisien dan efektif dibutuhkan sebuah aplikasi sebagai alat bantunya. Menurut Daya et al. (2018) blocplan adalah alat bantu yang digunakan serta memiliki manfaat untuk proses perbaikan tata letak dengan memanfaatkan algoritma hybrid dengan memproses algoritma perbaikan. Terdapat manfaat dari blocplan adalah untuk meminimalkan jarak antara stasiun kerja dan mengembangkan korelasi antar stasiun kerja. Menurut Ulfauzi et al. (2020) kelebihan dari algoritma blocpalan adalah sudah memiliki kemampuan untuk menilai tingkat efisiensi, kedekatan, dan beberapa penilaian lainnya. Jadi perancan tidak perlu menguji hasilnya lagi melainkan langsung menilai skor yang dihasilkan untuk menentukan jenis tata letak yang paling efisien yang akan dirancang. Tetapi blocpan membutuhkan Activity Relationship Chart (ARC) atau skala kedekatan sebelum diinput blocpan.

\section{METODE PENELITIAN}

Pendekatan penelitian deskriptif kuantitatif digunakan dalam penelitian ini. Menurut Priyono (2016) dalam melakukan penelitian secara deskriptif memiliki fungsi untuk memberikan ilustrasi secara rinci tentang suatu fenomena dan gejala yang terjadi, dalam penyelesaiannya penelitian berupa pola fenomena yang sedang terjadi dan dilakukan pembahasan. Sedangkan pendekatan kuantitatif menurut Mulyadi (2011) pendekatan menggunakan kuantitatif menimbulkan persoalan atau masalah dalam mengendalikan faktor dan variabel yang lainnya bisa mempengaruhi 
proses penelitian baik secara nyata maupun tidak nyata, demi terciptanya keabsahan data secara real juga harus diperhatikan proses menentukan samping, dan penentuan metode, alat bantu yang digunakan untuk analisis.

Dalam melakukan penelitian ini menggunakan definisi operasinal variabel sebagai berikut:

1. Layout fasilitas produksi atau pabrik

Pengukuran layout dapat diukur menggunakan satuan meter dan pengukurannya dengan mengukur bagian luas pabrik dan tiap stasiun kerja hingga mesin didalam pabrik.

2. Jarak

Perhitungan jarak menggunakan perhit ungan Rectilinear.

3. Software Blocplan

Software Blocplan merupakan alat bantu yang berguna untuk melakukan efisiensi dalam hal perbaikan tata letak.

Pendekatan penelitian deskriptif kuantitatif digunakan dengan membutuhkan data yang nantinya akan dilakukan analisis. teknik pengumpulan data sebagai beriikut :

\section{Data primer}

terdiri dari : data besaran produksi, ukuran luas area produksi, ukuran jarak fasilitas produksi, tata letak produksi awal, peralatan produksi dan harganya, data gaji pekerja

2. Data sekunder

Didapatkan dari buku yang berkaitan atau jurnal penelitian.

Dalam melakukan pengkajian, maka dibutuhkan data yang akan dipakai dalam penelitian ini untuk memecahkan masalah, Adapun data primer yang dibutuhkan adalah data ukuran setiap stasiun kerja dalam produksi, tata letak produksi awal, dan alur dalam pemprosesan produksi. Data peralatan produksi, dan data gaji pekerja. Data yang akan diperoleh dalam pengamatan tersebut akan digunakan untuk bahan dan sebagai pertimbangan perbaikan dengan merancang ulang tata letak produksi UD. Barokah Lamongan. Setelah semua data didapatkan maka diproses dengan software blocplan, berikut merupakan langkah penggunaannya (Daya et al., 2018):

1. Memasukkan input data. Total bagian departemen, dan luas area dalam stasiun kerja

2. Nilai Activity Relationship Chart (ARC) menggunakan simbol atau tanda hubungan antar departemen yang dapat diatur oleh setiap pengguna blocplan.

3. Blocplan akan memproses dan akan menunjukkan nilai setiap departemen. atau stasiun kerja

4. Software blocplan akan menunjukkan lima macam pilihan rasio dan ukuran bentuk yang akan dipilih.

5. Blockplan menampilkan pilihan alternatif (maksimal 20 pilihan alternatif). Dan alternatif dengan skor tertinggi merupakan pilihan yang terbaik.

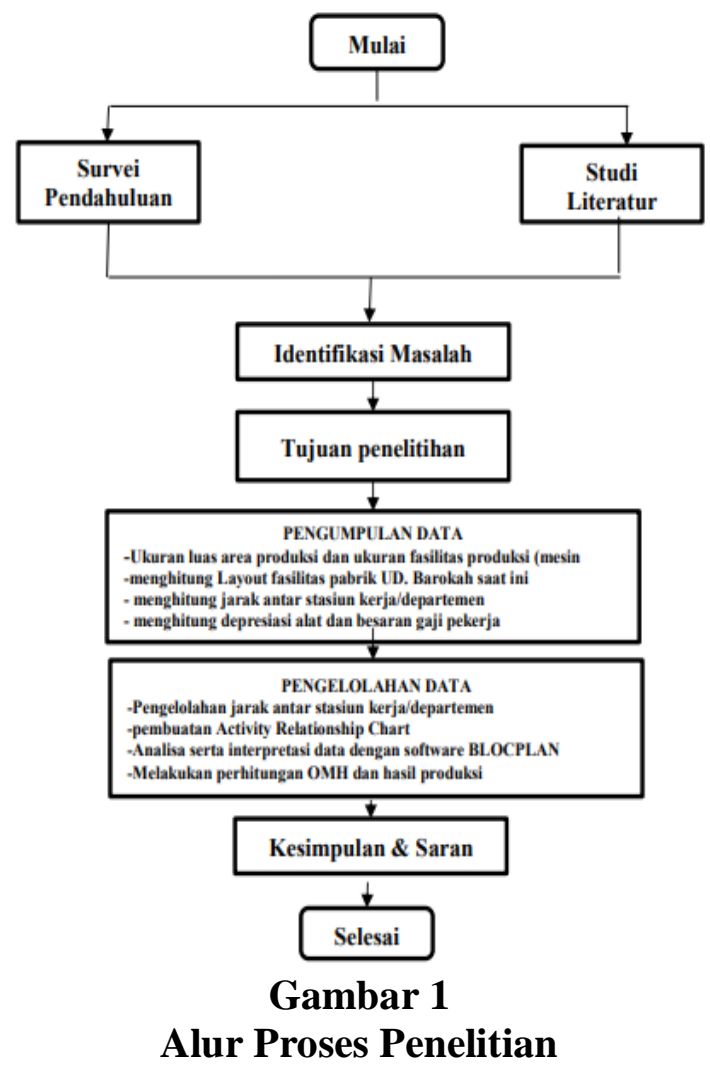




\section{HASIL DAN PEMBAHASAN \\ Luas Masing-Masing Fasilitas Produksi}

Luas masing-masing fasilitas produksi ini diukur dengan pengamatan langsung dan pengukuran secara langsung dari proses awal produksi snack hingga akhir produksi menjadi barang jadi.

Tabel 3

Ukuran Fasilitas Produksi UD. Barokah

\begin{tabular}{|c|c|c|c|c|}
\hline No & Nama Fasilitas & Simbol & Ukuran & Luas $\left(\mathrm{M}^{2}\right)$ \\
\hline 1 & $\begin{array}{l}\text { Gudang bahan } \\
\text { baku }\end{array}$ & $A$ & $5,4 \times 3,5$ & 18,9 \\
\hline 2 & $\begin{array}{l}\text { Pencampuran } \\
\text { adonan }\end{array}$ & B & $3 \times 2,5$ & 7,5 \\
\hline 3 & Perebusan & $\mathrm{C}$ & $4,3 \times 2$ & 8,6 \\
\hline 4 & $\begin{array}{l}\text { Pencetakan } \\
\text { adonan }\end{array}$ & D & $4 \times 2,6$ & 10,4 \\
\hline 5 & Pengeringan & $E$ & $2 \times 1,4$ & 2.8 \\
\hline 6 & Pemotongan & $F$ & $2,5 \times 1,7$ & 4,25 \\
\hline 7 & Penggorengan & G & $6 \times 3$ & 18 \\
\hline 8 & $\begin{array}{l}\text { Pencampuran } \\
\text { bumbu }\end{array}$ & $\mathrm{H}$ & $2,5 \times 1,3$ & 3,25 \\
\hline 9 & Pengemasan & 1 & $4,5 \times 3$ & 13,5 \\
\hline \multirow[t]{2}{*}{10} & $\begin{array}{l}\text { Gudang } \\
\text { pengiriman }\end{array}$ & J & $6, \times 2,7$ & 16,2 \\
\hline & Total & & & 103,4 \\
\hline
\end{tabular}

Sumber : UD. Barokah Lamongan

Berdasarkan tabel 3 diatas maka menunjukkan luas ukuran stasiun kerja atau tiap bagian departemen masingmasing yang diperoleh dari pengukuran secara manual dengan satuan meter di UD. Barokah Lamongan.

Setelah mendapatkan ukuran setiap stasiun kerja, maka akan dilakukan penyesuaian ukuran.

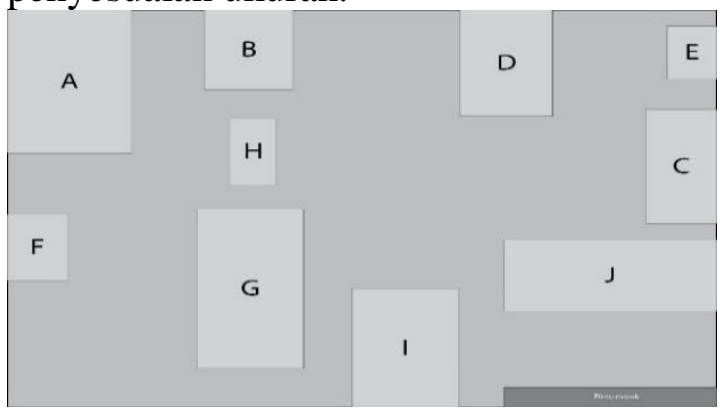

Keterangan :

$\mathrm{A}=$ Gudang bahan baku $\quad \mathrm{F}=$ Pemotongan

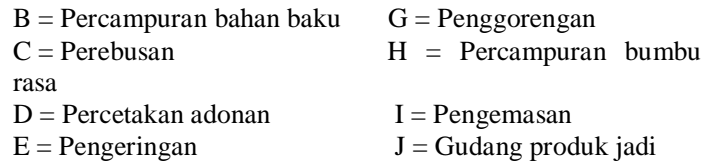

\section{Gambar 2}

Tata Letak Awal UD. Barokah

\section{Lamongan}

Dari gambar 2 merupakan penyesuaian ukuran dan lokasi penempatan tata letak awal yang dilakukan penggambaran di aplikasi Corel Draw. Dalam gambar 2 juga terdapat urutan proses produksi yang dimulai dari huruf A dan berakhir dengan huruf $\mathbf{J}$ serta terdapat keterangan jenis stasiun kerja. Tata letak awal Pada tabel 3 dan gambar 2 merupakan bagian yang dibutuhkan sebagai data pendukung untuk menganalisis usulan tata letak baru yang menghasilkan layout dan biaya perpindahan bahan baku produksi yang efisien. Dalam prakteknya proses produksi snack di UD. Barokah diawali dengan beberapa tahap sebagai berikut :

1. Pengambilan bahan baku di gudang

2. Melakukan percampuran bahan baku

3. Melakukan perebusan bahan baku yang sudah dicampurkan

4. Melakukan pencetakan adonan menjadi lontongan panjang

5. Dilakukan pengeringan dengan diangin-anginkan

6. Dilakukan pemotongan

7. Dilakukan penggorengan

8. Setelah digoreng maka dimasukkan mesin untuk ditaburkan bumbu rasa

9. dilakukan pengemasan

10. diletakkan di gudang produk jadi

\section{Jarak Antar Fasilitas Produksi Awal}

Jarak antar fasilitas produksi berguna untuk mengetahui berapa besaran jarak antar bagian produksi, pengukurannya dengan cara menggambarkan masing-masing fasilitas produksi atau departemen yang sebenarnya dengan aplikasi Corel Draw seperti pada tabel 4. 
Tabel 4 Data Titik Setiap Fasilitas Produksi

\begin{tabular}{clccc}
\hline No & \multicolumn{1}{c}{ Nama Fasilitas } & Simbol & X & Y \\
\hline 1 & Gudang bahan baku & A & 1,75 & 2,7 \\
& & & & \\
2 & $\begin{array}{l}\text { Percampuran bahan } \\
\text { baku }\end{array}$ & B & 6,80 & 1,5 \\
3 & Perebusan & C & 19 & 5,90 \\
4 & Percetakan adonan & D & 14,07 & 2 \\
5 & Pengeringan & E & 19,3 & 1,60 \\
6 & Pemotongan & F & 0,85 & 8,95 \\
7 & Penggorengan & G & 6,85 & 10,50 \\
8 & Percampuran bumbu & H & 6,93 & 5,34 \\
& rasa & & & \\
9 & Pengemasan & I & 11,22 & 12,75 \\
10 & Gudang produk jadi & J & 17 & 10,01 \\
& & & & \\
\hline
\end{tabular}

Sumber : Aplikasi Corel Draw

Dari tabel 4 merupakan penentuan data titik pusat suatu stasiun kerja satu dengan lainya, setelah data tersebut ditemukan maka dapat dilakukan proses menghitung jarak departemen atau fasilitas produksi.

\section{Frekuensi, jarak, dan Total Momen Perpindahan Awal}

Frekuensi Perpindahan adalah berapa jumlah setiap kali para pekerja melakukan pemindahan secara manual bahan baku antar departemen atau stasiun kerja. Untuk mendapatkan data tersebut dengan cara melakukan wawancara kepada pemilik pabrik dan melakukan pengamatan secara langsung untuk membuktikannya. Sedangkan untuk mencari total momen perpindahan dengan cara :

(jarak departemen x Frekeunsi)

Sedangkan untuk mencari jarak antar departemen dilakukan perhitungan dari data pada tabel 4 dengan menggunakan metode pengukuran rectiliniear dengan rumus berikut:

$$
|x i-x j|+|y i-y j .|
$$

Tabel 5

Data Jarak , Frekuensi, perpindahan

awal

\begin{tabular}{cccc}
\hline $\begin{array}{c}\text { Aliran } \\
\text { Material }\end{array}$ & $\begin{array}{c}\text { Jarak } \\
\text { Deparemen } \\
(\mathbf{m})\end{array}$ & $\begin{array}{c}\text { Frekuensi } \\
\text { (f) }\end{array}$ & $\begin{array}{c}\text { Total Jarak } \\
\text { Perpindahan } \\
\text { (Z) M/hari }\end{array}$ \\
\hline A-B & 6,25 & 12 & 75 \\
B-C & 16,6 & 40 & 664 \\
C-D & 8,2 & 35 & 287 \\
D-E & 5,63 & 30 & 168,9 \\
E-F & 25,8 & 30 & 774 \\
F-G & 7,55 & 28 & 211,4 \\
G-H & 5,24 & 70 & 366,8 \\
H-I & 11,7 & 60 & 702 \\
I-J & 8,52 & 45 & 383,4 \\
\hline TOTAL & 95,49 & $350 /$ hari & $3,632,5 /$ hari \\
\hline Sumber $:$ UD & Barokah Lam
\end{tabular}

Sumber : UD. Barokah Lamongan (data diolah

Dari tabel 5 dapat diketahui data tiap proses aliran kerja, jarak antar departemen satu dengan lainnya, frekuensi perpindahan, dan total jarak perpindahan, data tersebut sangat penting digunakan dalam pemprosesan dengan blocplan dan digunakan untuk perhitungan untuk menentukan efisiensinya. Untuk selanjutnya adalah mencari total jarak perpindahan/tahun dan mencari total momen perpindahan dalam waktu satu jam dengan cara :

(Total momen perpindahan $\mathrm{x}$ total hari kerja selama setahun)

$$
3,632,5 \times 300=1,089,750 \mathrm{~m} / \text { tahun. }
$$

(Total momen perpindahan : jam kerja

$$
\text { satu hari) }
$$

$$
\text { 3,632,5: } 8=454,07 \mathrm{~m} / \mathrm{jam}
$$

\section{Perhitungan Biaya atau Ongkos Material Handling}

Biaya material handling dapat terjadi karena adanya perpindahan bahan antar departemen maupun stasiun kerja, jika biaya material handling bisa ditekankan lebih minimal maka biaya 
yang dikeluarkan pihak perusahaan akan semakin minimal juga. Menurut Sari (2018) Untuk mencari depresiasi perbulan peralatan naterial handling dengan rumus:

$$
\text { Depresiasi }=\frac{\text { ongkos awal }- \text { nilai sisa }}{\text { masa paka optimal }}
$$

Dan dibagi perjam untuk mencari angka depresiasi perjam.

\section{Tabel 6}

\begin{tabular}{lccccc}
\multicolumn{5}{c}{ Peralatan Material Handling UD. } \\
Barokah Lamongan
\end{tabular}

Sumber UD. Barokah Lamongan (data diolah)

Pada tabel 6 merupakan data alat material handling yang digunakan Untuk proses perpindahan bahan dalam proses produksi dan terdapat harga saat dilakukan pembelian awal. Setelah dilakukaan perhitungan maka ditemukan total biaya depresiasi perjam sebesar Rp. 925.53.

Tabel 7

Gaji Karyawan UD. Barokah Lamongan

\begin{tabular}{ccccc}
$\begin{array}{c}\text { Jumlah } \\
\text { Karyawan }\end{array}$ & $\begin{array}{c}\text { Gaji } \\
\text { Kerja/ } \\
\text { Hari }\end{array}$ & $\begin{array}{c}\text { Gaji } \\
\text { Kerja/ } \\
\text { jam }\end{array}$ & $\begin{array}{c}\text { Jam } \\
\text { Kerja/ } \\
\text { hari }\end{array}$ & $\begin{array}{c}\text { Total Gaji } \\
\text { Karyawan/ } \\
\text { Jam }\end{array}$ \\
\hline 18 & Rp. 80.000 & Rp. 10.000 & 8 & Rp. 180.000 \\
\hline
\end{tabular}

Sumber : UD. Barokah Lamongan
Dari tabel 7 dapat diketahui bahwa terdapat jumlah keseluruhan karyawan yang bekerja dan terdapat juga besaran rincian gajinya, data tersebut digunakan untuk perhitungan besaran ongkos material handling awal. Berikut ini merupakan rumus untuk melakukan perhitungan ongkos material handling (Setiyawan et al., 2017):

Biaya/Ongkos $\mathrm{OMH} / \mathrm{m}=$

$\frac{\text { Depresiasi Alat + Biaya Tenaga Kerja }}{\text { Jarak Angkut Per Jam }}$

$$
\frac{R p .925,53+R p .180 .000 .00}{454,07 m}=398.45
$$

$\mathrm{OMH} / \mathrm{hari}=\mathrm{Z} \times \mathrm{OMH} / \mathrm{m}$

$=3,632,5 \mathrm{~m} \mathrm{X} \mathrm{398,45,00}$

$=1.447 .369 . /$ hari.

Jika dijumlahkan selama 1 tahun maka dapat diketahui Rp.434,210,700.

\section{Pembuatan Tata Letak Usulan}

Menentukan peta keterkaitan ARC merupakan tahapan awal untuk perancangan Blocplan.

\begin{tabular}{|c|c|c|c|c|}
\hline Kode & Wama & Derajat kedelkatan & NO & Alasan Kedekatan \\
\hline $\bar{A}$ & & MuttlakPerlu & 1 & Aliran Kerja \\
\hline E & & Sangat Penting & 2 & Kebisingan, Kotoran, debu, bau \\
\hline I & & Penting & 3 & Keterkaitan Produksi \\
\hline 0 & & Biasa & 4 & Penggunaan Peralatan sama \\
\hline $\mathrm{U}$ & & Tidak Perlu & 5 & Tidak ada hubungan kerja \\
\hline X & & Tidak dinginkan & & \\
\hline
\end{tabular}

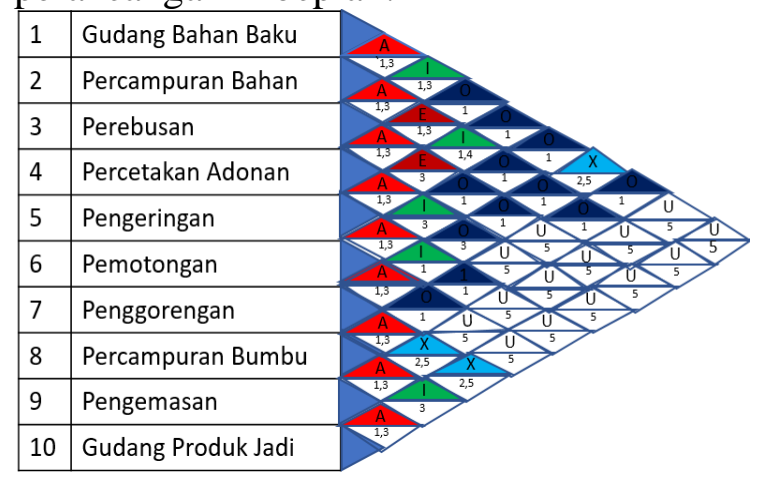

Gambar 3

Activity Relationship Chart (ARC) UD. Barokah Lamongan

Setelah penentuan ARC maka tahap selanjutnya adalah melakukan 
analisis dengan menggunakan software blocplan, berdasarkan data input dan kedekatan menurut Activity Relationship Chart (ARC).

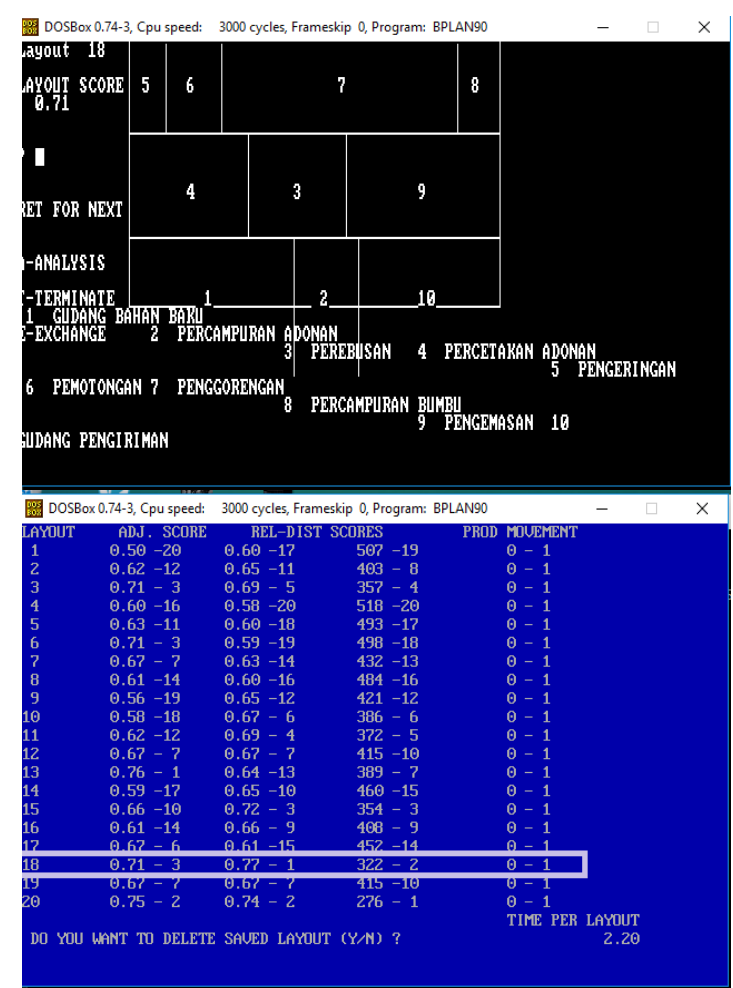

\section{Gambar 4 \\ Hasil Tata Letak Metode Blocplan}

Gambar 4 menjelaskan pola tata letak yang baru setelah dilakukan pemprosesan dengan blocplan, alasan memilih no 18 untuk layout yang terbaik dikarenakan hasil iterasi dari total 20 iterasi tersebut bahwa pada iterasi ke 18 memiliki R-Score yang maksimal atau yang sangat tinggi dengan angka 0,77.

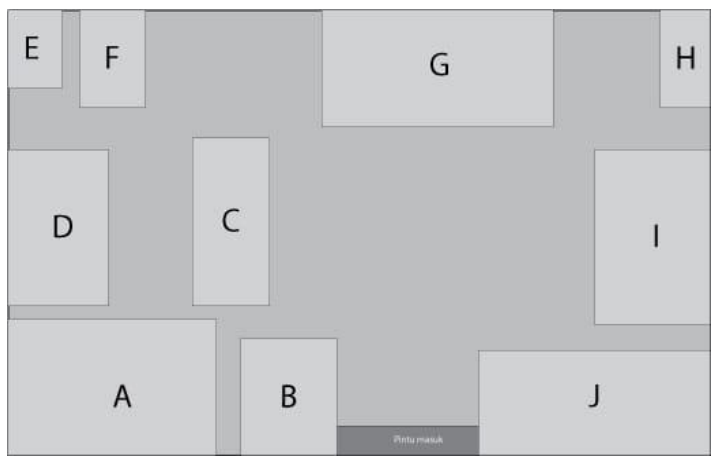

Gambar 5

Penyesuaian Dari Metode Blocplan
Pada gambar 5 merupakan penyesuaian dengan kondisi yang sebenarnya dari gambar 4. Yang sudah mendapatkan pola tata letak baru dengan blocplan.

\section{Data Kordinat dan Data Jarak Depart emen, Frekuensi Metode Blocplan}

Setelah dilakukan pemprosesan dengan blocplan maka akan didapatkan juga data kordinat setiap stasiun kerja.

Tabel 8

\section{Data Kordinat Aplikasi Blocplan}

\begin{tabular}{clccc}
\hline No & Nama Fasilitas & Simbol & $\mathbf{X}$ & $\mathbf{Y}$ \\
\hline 1 & Gudang bahan baku & A & 2,26 & 2,09 \\
2 & Percampuran bahan & B & 5,41 & 2,09 \\
& baku & & & \\
3 & Perebusan & C & 4,60 & 5,79 \\
4 & Percetakan adonan & D & 1,63 & 5,79 \\
5 & Pengeringan & E & 0,50 & 8,78 \\
6 & Pemotongan & F & 1,77 & 8,78 \\
7 & Penggorengan & G & 5,77 & 8,78 \\
8 & Percampuran bumbu & H & 9,58 & 8,78 \\
& rasa & & & \\
9 & Pengemasan & I & 8,06 & 5,79 \\
10 & Gudang produk jadi & J & 8,24 & 2,09 \\
\hline Sumber
\end{tabular}

Sumber software blocplan

Pada tabel 8 adalah titik kordinat yang baru, titik kordinat tersebut nantinya akan dilakukan perhitungan dan akan dibandingkan dengan titik kordinat sebelum dilakukan perbaikan.

\section{Tabel 9}

Data Jarak , Frekuensi, Perpindahan Dengan Blocplan

\begin{tabular}{cccc}
\hline $\begin{array}{c}\text { Aliran } \\
\text { Material }\end{array}$ & $\begin{array}{c}\text { Jarak } \\
\text { Deparemen } \\
(\mathbf{m})\end{array}$ & $\begin{array}{c}\text { Frekuensi } \\
(\mathbf{f})\end{array}$ & $\begin{array}{c}\text { Total Jarak } \\
\text { Perpindahan }\end{array}$ \\
\hline A-B & 3,15 & 12 & 37,8 \\
B-C & 4,51 & 40 & 180,4 \\
C-D & 2,79 & 35 & 97,65 \\
D-E & 4,12 & 30 & 123,6 \\
E-F & 1,27 & 30 & 38,1 \\
F-G & 4 & 28 & 112 \\
G-H & 3,81 & 70 & 266,7 \\
H-I & 4,51 & 60 & 270,6 \\
I-J & 3,88 & 45 & 174,6 \\
\hline TOTAL & 32,04 & 350 & $1.301,5$ \\
\hline Sumber : Software blocplan &
\end{tabular}


Pada tabel 9 merupakan data setelah dilakukan perbaikan dengan blocplan yang berasal dari data titik kordinat pada tabel 8 dan dilakukan perhitungan untuk menemukan tiap bagiannya. Berikut ini merupakan rumus perhitungan biaya/ongkos material handling dengan data berasal dari software blocplan : (Setiyawan et al., 2017)

Biaya/Ongkos OMH/hari = z X OMH/m

$=1.301,5 \mathrm{~m} \mathrm{X} \mathrm{398,45,00}$

$=518.582 .68 /$ hari

Tata letak dengan memakai software blocplan dapat diketahui menghasilkan total momen perpindahan sebesar 1.301,5 m/hari, jika dilakukan perhitungan selama setahun maka total momen perpindahan selama setahun sebesar 390,450 m/tahun, Setelah dilakukan perhitungan mendapatkan hasil biaya perpindahan ongkos material handling selama sehari adalah $\mathrm{Rp}$. 518.582.68/hari, jika dijumlahkan selama setahun adalah Rp. 155.574.804/tahun. Jika dibandingkan sebelum perbaikan dan sesudah perbaikan tata letak dengan mengunakan software blocplan terjadi penghematan ongkos material handling sebesar Rp. 278.635.876/tahun.

\section{Perhitungan Perbandingan Waktu Produksi}

Dengan lebih baiknya proses produksi dapat mengubah output produksi yang berdampak semakin besarnya jumlah produk yang dihasilkan, berikut ini merupakan perhitungan efisiensi waktu:

$\frac{\text { Momen awal }}{\text { Momen blocplan }} \quad=\frac{\text { Waktu produksi awal }}{\text { Waktu produksi dengan blocplan }}$
$\begin{array}{ll}\frac{\mathbf{3 . 6 3 2 . 5 0 ~ m}}{\mathbf{1 . 3 0 1 . 5 0 ~ m}} & =\frac{\mathbf{8 ~ J a m}}{X \mathrm{Jam}} \\ 10.412 & =3.632 .50 \\ X \quad & =2.86\end{array}$

Bedasarkan perhitungan dapat diketahui kondisi saat ini produksi snack adalah 8 jam dalam waktu sehari, berdasarkan perhitungan dengan tata letak usulan dengan menggunakan alat bantu software blocplan dapat lebih cepat hanya membutuhkan waktu 3 jam. Dengan ini maka metode blocplan dapat mengurangi waktu produksi secara signifikan hingga 5 jam per hari sehingga berdampak pada output produksi yang semakin banyak.

Dalam menentukan perbandingan output produksi menggunakan data empat bulan terakhir dan akan dipilih output produksi yang paling besar yaitu pada bulan April 2021 yang ditunjukkan pada tabel 2.

1. Produksi makaroni

Sebelum dilakukan perbaikan 26 Ball/Jam, 204 Ball/hari 5.100 Ball per bulan.

Jika dengan blocplan bisa perjam 68 ball/jam. Perhari 544 ball/ dan perbulan 13.600 ball/bulan.

2. Produksi bakso goreng

Sebelum dilakukan perbaikan 8 Ball/Jam, 64 Ball/hari 1.600 Ball per bulan.

Jika dengan blocplan bisa perjam 21 ball/jam. Perhari 168 ball/ dan perbulan 4.200 ball/bulan

Berikut ini tabel perbandingan secara lengkap sebelum dilakukan perbaikan dan sesudah dilakukan perbaikan dengan menggunakan software blocplan.

Tabel 10

Perbandingan Ongkos Material Handling UD. Barokah Lamongan

\begin{tabular}{lcc}
\hline Tata letak & $\begin{array}{c}\text { Momen } \\
\text { perpindahan } \\
\text { /tahun }\end{array}$ & $\begin{array}{c}\text { Ongkos material } \\
\text { handling/tahun }\end{array}$ \\
\hline Awal & $1,089,750$ & Rp. 434,210,700 \\
$\begin{array}{l}\text { Metode } \\
\text { Blocplan }\end{array}$ & 390,450 & Rp. 155.574.804 \\
$\begin{array}{l}\text { Tingkat } \\
\text { Efisiensi }\end{array}$ & $64,1 \%$ & $64,1 \%$ \\
\hline
\end{tabular}


Tabel 11

Perbandingan Output Produksi UD. Barokah Lamongan

\begin{tabular}{lcc}
\hline Tata letak & $\begin{array}{c}\text { Makaroni/ } \\
\text { Bulan }\end{array}$ & Bakso goreng/bulan \\
\hline Awal & 5.100 ball & 1.600 ball \\
Metode Blocplan & 13.600 ball & 4.200 ball \\
\hline
\end{tabular}

\section{Pembahasan}

Berdasarkan hasil penelitian diatas yang sudah dilaksanakan, maka dapat dilakukan pembahasan bahwa terjadi perubahan secara signifikan sebelum dilakukan proses perbaikan dan sesudah dilakukan perbaikan dengan metode blocplan, setelah dilakukan perbaikan terdapat penghematan momen perpindahan dengan selisih 699,300 $\mathrm{m} /$ tahun, ongkos material handling dengan selisih Rp. 278,635,896/tahun dan terjadi penambahan output produksi makaroni sebesar 8.500 ball/bulan dan bakso goreng sebesar 2.600 ball/bulan. Dengan berkurangnya momen perpindahan, dan ongkos material handling serta bertambahnya output produksi, terdapat manfaat yang sangat besar dalam melakukan perbaikan tata letak pada UD. Barokah Lamongan yang akan memberikan manfaat pada peningkatan keuntungan perusahaan. Kondisi tersebut berkorelasi mengenai pandangan yang dikemukakan oleh Tarigan et al. (2018) bahwa perencanaan tata letak fasilitas yang efektif dapat secara signifikan menekan biaya operasi dan meningkatkan kinerja lini produksi. Selain itu hasil penelitian ini ditunjang dan didukung dengan hasil penelitian sejenis lainnya, seperti penelitian dilakukan oleh Pratiwi et al. (2012) dan Setiyawan et al. (2017) yang menjelaskan bahwa perbaikan tata letak produksi dengan memakai aplikasi blocplan berdampak pada peningkatan efisiensi sekitar 10\% hingga 30\%, efisiensi dapat meningkat jika bisa menekan biaya material handling, penghematan perpindahan jarak antar fasilitas produksi dan departemen, dan meminimalkan biay aoperasional, sehingga dapat membantu perusahaan untuk meningkatkan hasil produksi. Jika Sebelumnya UD. Barokah Lamongan belum bisa mencapai target produksinya sehingga belum bisa memenuhi permintaan pasar, setelah dilakukan perbaikan produksi maka perusahaan dapat meningkatkan hasil produksinya sehingga memenuhi permintaan pasar, maka dengan itu perbaikan produksi berdampak pada penjualan produk yang meningkat, dan berdampak pada perkembangan perusahaan. Disisi lain terdapat beberapa manfaat yang didapatkan oleh UD. Barokah Lamongan setelah dilakukannya perbaikan produksi yang lebih efisien, seperti harga pokok produksi yang semakin menurun jika dibandingkan sebelumnya, harga produk yang lebih kompetitif jika dibanding pesaingnya, serta akan berdampak pada laba yang semakin meningkat akibat penjualan produk yang lebih banyak dan bisa memenuhi target pasar. Semua hal tersebut yang akan memperbaiki dan mendongkrak daya saing usaha pada UD. Barokah Lamongan.

\section{SIMPULAN}

Berdasarkan pengkajian serta dilakukan analisis terhadap UD. Barokah Lamongan untuk permasalahan efisiensi tata letak fasilitas produksi, maka dapat diperoleh kesimpulan bahwa, tata letak fasilitas produksi snack setelah dilakukan perbaikan mampu menghasilkan pengurangan momen perpindahan sebesar 699,300 m/tahun. Dan biaya atau ongkos material handling sebesar Rp.278,635,896. Perbaikan tata letak produksi juga berdampak pada output produksi makaroni sebesar 13.600 ball/bulan dan bakso goreng 4.200 ball/bulan. Hasil produksi tersebut sudah melampaui target produksi UD. Barokah 
Lamongan. Hasil simulasi dengan blocplan sangat berpengaruh secara signifikan dan menghasilkan tingkat efisiensi momen perpindahan sebesar $64,1 \%$ per tahun, ongkos material handling $64,1 \%$ per tahun, dari perbaikan tata letak produksi dapat meningkatan hasil produksi makaroni sebesar $62 \%$ per bulan dan bakso goreng sebesar $61,5 \%$ per bulan akan mampu meningkatkan daya saing perusahaan seperti dapat memenuhi permintaan pasar yang sebelumnya belum bisa terpenuhi semua oleh perusahaan, barang dipasaran akan lebih banyak mendominasi jika dibandingkan dengan kompetitor, dan harga produk dipasaran akan lebih baik jika dibandingkan pesaingnya sehingga UD. Barokah Lamongan mendapatkan prospek yang sangat cerah yaitu dapat menguasai pasar domestik di wilayahnya.

Dari hasil kesimpulan tersebut terdapat saran yang diberikan pada penelitian selanjutnya yaitu melakukan simulasi perancangan tata letak dengan metode atau software lain seperti corelap, Quantity System For Business (QSB) atau software lain yang bisa digunakan untuk perancangan efisiensi tata letak, dari hasil perancangan tersebut akan dibandingkan dengan hasil penelitian saat ini dengan menggunakan software blocplan,

\section{DAFTAR PUSTAKA}

Abdilla, M., \& Agus, I. (2021). Keputusan Pembelian Online Saat Pandemi Covid 19 di Fakultas Ekonomi Dan Bisnis Universitas Dharma Andalas. Jurnal Ekonomi Dan Bisnis Dharma Andalas, 23(1), 123-134.

https://doi.org/10.47233/jebd.v23i1. 207

Amalia, R. R., Ariyani, L., \& Noor, M. (2017). Perancangan Ulang Tata Letak Fasilitas Industri Tahu dengan Algoritma Blocplan Di UD. Pintu Air. Teknologi Agro-Industri, 4(2),
89-100.

Araújo, M., Amaral, G., \& Varela, L. (2017). Improving productivity and standard time updating in an industrial company - A case study. International Journal of Mechatronics and Applied Mechanics, 2017(1), 139-144. https://doi.org/10.17683/ijomam.iss ue1.22

Damaledo, Y. D. (2019). Mondelez Rilis Survei Soal Kebiasaan \& Tren Ngemil Orang Indonesia. Tirto.Id. https://tirto.id/mondelez-rilissurvei-soal-kebiasaan-tren-ngemilorang-indonesia-emQF

Daya, M. A., Sitania, F. D., \& Profita, A. (2018). Perancangan Ulang (relayout) tata letak fasilitas produksi dengan metode blocplan (studi kasus: ukm roti rizki, Bontang). PERFORMA Media Ilmiah Teknik Industri, 17(2), 140-145. https://doi.org/10.20961/performa.1 7.2.29664

Habi Adi, I., \& Handayani, W. (2020). Perancangan ulang tata letak gudang produk untuk meningkatkan efesiensi proses bongkar muat. 6. https://jurnal.narotama.ac.id/index.p hp/patria/article/view/1092

Hari Prasad, N., Rajyalakshmi, G., \& Sreenivasulu Reddy, A. (2014). A typical manufacturing plant layout design using CRAFT algorithm. Procedia Engineering, 97(December 2014), 1808-1814. https://doi.org/10.1016/j.proeng.201 4.12.334

Irawan, D. (2020). Peningkatan Daya Saing Usaha Micro Kecil dan Menengah Melalui Jaringan Usaha. Coopetition: Jurnal Ilmiah Manajemen, XI(2), 103-116. https://www.neliti.com/id/publicati ons/325683/

Kovács, G., \& Kot, S. (2017). Facility 
layout redesign for efficiency improvement and cost reduction. Journal of Applied Mathematics and Computational Mechanics, 16(1), 63-74.

https://doi.org/10.17512/jamcm.201 7.1 .06

Mufida, I., Kurniati, R. R., \& Zunaida, D. (2019). Pengaruh Faktor Bahan Baku dan Bahan Penolong Terhadap Produksi. Jiagabi, 8(1), 51-58.

Muin, M. (2017). Pengaruh Faktor Produksi Terhadap Hasil Produksi Merica Di Desa Era Baru Kecamatan Tellulimpoe Kabupaten Sinjai. Jurnal Economix, 5(2), 203214.

https://ojs.unm.ac.id/economix/artic le/view/5374/3114

Mulyadi, M. (2011). Penelitian Kuantitatif Dan Kualitatif Serta Pemikiran Dasar Menggabungkannya [Quantitative and Qualitative Research and Basic Rationale to Combine Them]. Jurnal Studi Komunikasi Dan Media, 15(1), 128.

Nadia, N., \& Lai-Soon. (2016). Heuristics and Metaheuristics Approaches for Facility Layout Problems: A Survey. Pertanika Journal of Scholarly Research Reviews, 2(3), 62-76.

http://www.pjsrr.upm.edu.my/

Okpala., Chikwendu., \& Okechukwu. (2016). Plant Layouts' Analysis and Design. International Journal of Advanced Engineering Technology E- Int J Adv Engg Tech, July 2016, 201-206.

Pratiwi, I., Muslimah, E., \& Aqil, A. W. (2012). Perancangan Tata Letak Fasilitas Di Industri Tahu Menggunakan Blocplan Indah. Jurnal Ilmiah Teknik Industri, 11(2). https://doi.org/10.20961/performa.1 7.2.29664
Priyono. (2016). Metode Penelitian Kuantitatif (2016th ed.).

Puspita, I. A., Iqbal, M., Pratami, D., \& Pratomo, A. (2015). Production facility layout design using blocplan algorithm. Advanced Science Letters, 23(5), 3917-3920. https://doi.org/10.1166/asl.2017.82 60

Sari, D. I. (2018). Analisis Depresiasi Aktiva Tetap Metode Garis Lurus dan Jumlah Angka Tahun PT Adira Dinamika. Jurnal Moneter, V(1), 86-92.

Setiyawan, D. ., Qudsiyyah, D. ., \& Mustaniroh, S. . (2017). Usulan perbaikan tata letak fasilitas produksi kedelai goreng dengan metode blocplan dan corelap (studi kasus pada UKM MMM di Gading Kulon, Malang). Jurnal Teknologi Dan Manajemen Agroindustri, 6(1), 51-60.

https://industria.ub.ac.id/index.php/i ndustri/article/view/263

Siregar, R. M., Sukatendel, D., Tarigan, U., Industri, D. T., Teknik, F., Utara, U. S., \& Handling, M. (2013). Perancangan Ulang Tataletak Fasilitas Produksi Dengan Menerapkan Algoritma Blocplan Dan Algoritma Corelap Pada Pt. Xyz. Jurnal Teknik Industri USU, 1(1), 35-44.

Tarigan, U., Tarigan, U. P. P., \& Rifangi, A. R. (2018). Application of lean manufacturing method and BLOCPLAN algorithm for productivity improvement of a laundry soap bar production. MATEC Web of Conferences, 197. https://doi.org/10.1051/matecconf/2 01819714004

Tongur, V., Hacibeyoglu, M., \& Ulker, E. (2020). Solving a big-scaled hospital facility layout problem with metaheuristics algorithms. Engineering 
Science and Technology, an International Journal, 23(4), 951959.

https://doi.org/10.1016/j.jestch.201 9.10.006

Tripathi, R. (2020). Plant Layout - Types and Trends. International Journal of Scientific and Research Publications, 1(1), 1-6.

Turanoğlu, B., \& Akkaya, G. (2018). A new hybrid heuristic algorithm based on bacterial foraging optimization for the dynamic facility layout problem. Expert Systems with Applications, 98(October), 93-104. https://doi.org/10.1016/j.eswa.2018. 01.011

Ulfauzi, Z., Artana, K. B., \& Handani, D. W. (2020). Application of BLOCPLAN algorithm as liquified natural gas (LNG) regasification terminal design method. IOP Conference Series: Earth and Environmental Science, 557(1). https://doi.org/10.1088/17551315/557/1/012021

Vaidya, R. D., Shende, P. N., Ansari, N. A., \& Sorte, S. M. (2013). Analysis of Plant Layout for Effective Production 501. 3, 500-504.

Yuliarty, P., \& Widiarto, I. (2014). Perancangan ulang tata letak lantai produksi menggunakan metode systematic layout planning dengan software blocplan pada PT. Pindad. Jurnal Ilmiah Teknik Industri, 2(3), 159-167.

Zúñiga, E. R., Moris, M. U., Syberfeldt, A., Fathi, M., \& Rubio-Romero, J. C. (2020). A simulation-based optimization methodology for facility layout design in manufacturing. IEEE Access, 8, 163818-163828.

https://doi.org/10.1109/ACCESS.20 20.3021753 